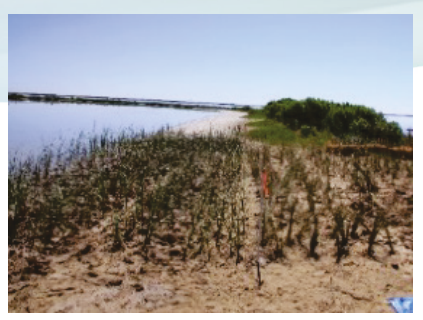

\title{
Plant Community Approach to Establishing Vegetation on DMPAs and CDFs
}

\author{
By Pamela Bailey, Sarah Miller, Tim Cary, Scott Bourne, \\ and Tosin Sekoni
}

PURPOSE: This technical note (TN) is the second in a series about using native plant communities to enhance Dredge Material Placement Areas (DMPAs) and Confined Disposal Facilities (CDFs). Project goals include the following: 1) introducing the dredging community to the benefits associated with native plant communities, and 2) demonstrating how targeted vegetation establishment can enhance DMPA and CDF management to improve engineering and environmental outcomes.

BACKGROUND: DMPAs and CDFs provide for temporary or permanent containment of material produced during dredging of navigable channels in waters of the United States, including bays, inland rivers, harbors, and berthing areas. Opportunistic plant species tend to colonize DMPAs/CDFs during idle periods or following closure, often resulting the establishment monocultures consisting of undesirable plant species. For example, some active DMPAs/CDFs must be managed to prevent excessive vegetation growth that may interfere with disposal operations. Following the closure of a CDF, active native plant communities offer ecological benefits, physical stability, and socio-economic benefits to the navigation mission.

The use of native vegetation to improve engineering and environmental objectives has been documented in a wide variety of landscapes (Smith et al. 2000; Danielson et al. 2005). For example, Bailey (2014) highlights the use of native vegetation to improve structural stability, erosion control, climatic regulation, aesthetics, architecture, and conservation within a range of ecological restoration projects. Despite the potential benefits associated with establishing native plant communities, few $\mathrm{CDF} / \mathrm{DMPA}$ designs incorporate vegetation into construction and management plans. As a result, the following sections highlight the benefits of native vegetation and introduces operations and maintenance staff to common planting techniques and considerations.

BENEFITS TO DMPAs and CDFs: Hundreds of DMPAs and CDFs have been built in the United States according to the Corpsmap database (https://geoplatform.usace.army.mil/home). The establishment of native plant communities provides an attractive, cost-effective, and environmentally compatible way to help maintain and enhance CDFs and DMPAs. The following highlight benefits associated with properly managed vegetative communities.

Aesthetics and microclimate benefits. Targeted plantings can increase aesthetics, improving public sentiment toward the management of federal lands (Jones and Hanna 2004). Establishing 
plant communities creates habitat (shelter and food) for fauna and aids in the recruitment of native vegetation through seed interception, pollinator activity, and improvement of soil conditions. Plants can also modify the local climate and create microclimates by providing shade, shelter belts, and wind breaks, all promoting further vegetation establishment while providing improved scenery (Asano 2006; Gómez-Aparicio et al. 2004).

Water quality and erosion control. Establishing vegetation filters and sequesters suspended sediments, decreasing soil erosion and preventing the introduction of nutrients and other compounds into adjacent aquatic systems. As a result, vegetated DMPAs and CDFs prevent sedimentation of adjacent waterways, improving water quality and clarity (Broome et al. 1988). Planted vegetation protects slopes and shorelines against erosion caused by wind and wave action (Comoss et al. 2002). The structural integrity of hillsides, slopes, construction sites, and other managed areas can be enhanced through establishment of vegetation, this has been shown to maintain slope and limit dust disturbance.

Dewatering benefits. Planted vegetation can play a role in water use and management, including increasing dewatering and consolidation of sediments within CDFs and DMPAs. Greenhouse and accompanying field studies, conducted within a CDF, demonstrate that vegetated areas dewater dredged sediments to a greater extent than un-vegetated areas (Smith et al. 2009). Ripening has been demonstrated as an effective way to remove excess water from sediments. Ripening is the process of initial soil formation, resulting from dewatering water-logged sediments through the use of selected plant species (Smith et al. 2009). Plants have the ability to transpire, and in the process remove water from the soil. As plants open their stomata apertures to take in atmospheric carbon dioxide for photosynthesis, they lose water via transpiration. Transpiration rates vary in plants and can range from 4.8 millimeters $(\mathrm{mm})$ per day in Buffalograss (Buchloe dactyloides) to $45.4 \mathrm{~mm}$ per day in Purple nutsedge (Cyperus rotundus) (Shearman 1989; Brenzy et al. 1973). Ecophysiological factors that influence transpiration rate of plants include leaf area, leaf/root area ratio, leaf orientation, leaf size, leaf shape, leaf surface characteristics, leaf anatomy, stomata number, and stomata size (Kramer 1983).

Plants with the highest evapotranspiration rates are most useful for the purpose of dewatering, (Smith et al. 2009). Hydrophytes are particularly of interest in dewatering because they are adapted to water surplus environments, and therefore, continuously open up their stomatal apertures to maximize photosynthesis (Pisek and Berger 1938). In a study conducted by Smith et al. (2009), Spartina pectinata and Salix nigra dewatered at (18.4g water/g soil) and (0.161g water/g soil) respectively, and were both determined to be effective at sediment dewatering.

Coastal resilience benefits. The placement areas themselves (whether nearshore CDFs or islands) contributes to coastal resilience by providing protection from storm surge while adding structural integrity for living shorelines (Walker et al. 2011; Bridges et al. 2015), and contributing ecological benefits such as wildlife habitat and linkage of greenways to sustain migratory fauna (Berkowitz et al. 2017).

Biotechnical application benefits. Implementing native plant biotechnical treatments in the context of CDFs/DMPAs has the potential to reduce dust, halt erosion, and prevent subsequent land loss, as these areas are under construction. This serves the dual purpose of creation and stabilization of living shorelines while preventing water quality degradation due to sediments. In undisturbed, 
unchanging, or low energy settings, banks or shorelines can often remain stable or erode very slowly over time, held in place by natural vegetation as it migrates in response to changing sea level or other conditions. In a disturbed, rapidly changing, or high energy environment, vegetation may be absent or may not be sufficient to hold shoreline or nearshore sediments in place. In some high energy environments, even fully mature vegetation may not be sufficient to hold the shoreline or bank, requiring a more structural approach. The following three categories of shoreline restoration for the purposes of stabilization can be considered: 1) purely vegetative solutions, 2) bioengineered, hybrid solutions, and 3) purely "hard" armor or structural solutions. Severely eroding sites may benefit from a combination of these approaches to maximize stability and minimize maintenance.

Biotechnical stabilization or bioengineering techniques are those where live pants and plant parts (primarily cuttings) are embedded in the ground and typically installed in patterns. These plants will sprout by adventitious rooting along the length of the embedded stems and branches. They hold the soil acting as soil reinforcements, barriers for sediment and earth movement, moisture wicks, and hydraulic drains. Methods include live staking, live fascines (wattling), brushlayering, branch packing, and live crib walls. Only plant parts such as stems and branches are harvested for biotechnical treatments, leaving the original plant alive in its source location. As the treatments develop, they can supply plant material in future years. These methods are cost-effective for materials, but labor-intensive to install. Many of these methods can be implemented primarily using hand labor or smaller sized heavy equipment.

SPECIES SELECTION: Vegetation propagation, growth, and survivability can be maximized by selecting native plant species on a regional basis, and establishing plant communities that are adapted to the particular physical, hydrologic, and climatic characteristics (e.g., temperature, sunlight intensity, fluctuations in available water). Environmental factors such as light intensity, climate, and soil conditions impact the establishment and survival of vegetative communities. Additionally, plant species display a range of tolerances to these factors. Some species are more adaptable, resulting in increased survival rates in locations with a range of conditions. As a result, planting a variety of species may lead to greater success by allowing plants to establish where the right conditions occur in micro-niches (e.g., hammocks). Ideally, efforts to establish plant communities in DMPAs and CDFs would mimic natural patterns of plant distribution and succession, maximizing engineering benefits and addressing project objectives while providing valuable habitat. In the natural community, diversity is generally higher when the community is establishing, with species composition changing over time. Often mature areas display reduced diversity as vegetation patterns stabilize and reach climax conditions (Bailey et al. 2015).

When establishing vegetation in DMPAs and CDFs, emphasis should be placed on selecting plant species tolerant to the surveyed conditions, rather than undertaking expensive ameliorative methods to improve the quality of dredge material/soils. Some physical parameters to consider include the following: soil bulk density, plant hardiness, tolerance to salt spray, tolerance to disease, optimum soil condition, optimum root zone moisture, drought tolerance, and tolerance to changes in water table including oxygen dynamics. The National Vegetation Classification (NVC) system and a Microsoft Excel spreadsheet developed by the authors provide guidance regarding plant species selection. In addition, local expertise should be sought for selecting species that are most tolerant of local conditions. 
National Vegetation Classification (NVC). The NVC is a system (Grossman et al. 1998) used by many federal agencies, including the U.S. Army Corps of Engineers (USACE) for its Level I and Level II survey efforts. This system can also be used for more detailed botanical inventories. To realize efficiency and cost savings, the USACE can use NVC data as a guide for selecting appropriate plant communities on projects, and for monitoring vegetation establishment success. Vegetation establishment, survivability, and long term sustainability will improve if appropriate species are selected based up NVC guidance. National Vegetation Classification data are scientifically defensible because the system is based upon NVC inventories and National Heritage Program resources. The NVC plant data are derived from the Nature Serve explorer website. (http://explorer.natureserve.org/) This website provides focus area plant communities that are reported in an Excel table.

Microsoft Excel plant data spreadsheet. The featured Excel table of plant communities is organized by the Baileys Ecoregion, NVC plant community, plant associations with the plants listed by their Latin binomial, common name, and the growth form (tree, shrub, herbaceous plantincluding grasses, or vine). Other characteristics of upmost importance are 1) whether the plant is salt tolerant and therefore can survive in coastal areas with salt spray, and 2) whether the plant has the capability to root adventitiously and therefore is suitable to consider in biotechnical treatments. This tool will be located as an active link at the EWN webpage. www. Engineering WithNature.org.

Specifications. Specifications are the legally binding documents that define how construction processes are to be accomplished, and are more important in that they are more binding than a design plan. The specification section for Landscape Establishment 30-05-33 of the USACE generic specifications can be found at http://specsintact.ksc.nasa.gov. These sections determine the necessary earthwork, type of soil required, amendments to the soil, types of plants, sizes, quantities, how to plant them, and requirements for care and survival.

\section{PLANTING RECOMMENDATIONS, TECHNIQUES, AND TOOLS}

Cultivation and soil conditions. Preparing dredge material by tilling, ploughing, disk harrowing and rototilling will break up the material, rid the surface of any existing vegetation, and incorporate nutrients or soil treatments. The texture of the dredge material soil should be able to promote aeration to the roots and facilitate root extension, this will improve nutrient and water uptake, allow infiltration of precipitation, and facilitate plant growth. Slope stability is a critical factor necessary to control surface erosion and provides a stable DMPA/CDF structure. As these features are constructed, soil conditions that provide for good drainage, erosion control, and support the development of plant communities is necessary. Soil $\mathrm{pH}$, nutrient content, texture, and other factors dictated by dredged material characteristics may have a direct bearing on the quality and type of plant growth.

Design of Seed Mixes. Seed mixes will be the most economical approach to planting large areas. Various seed treatments may be necessary for proper germination. Treatments include sowing fresh seed, cold moist stratification, warm moist stratification, cold dry stratification, inoculation, scarification, light treatment, and vegetative propagation. Sowing fresh seed works well for most spring flowering species. Seeds can be sown in flats to be set out when they have developed. 
Using certified seed is recommended because the seed has a known identity and meets certified quality standards for purity and germination (Natural Resources Conservation Service (NRCS) 2006). Certified seed has the best chance of success and the least chance of introducing unwanted seed problems. Varieties of seed have been developed and proven by the NRCS for specific geographic regions of the country. Native grass seed and often wildflower seed is sold on a pure live seed (PLS) basis and is recommended because it ensures that the desired product is what is being paid for, and protects against procurement of dead seed or unwanted plant pieces. A pound of pure live seed contains 16 ounces of living seed of the desired species plus additional weight of the other material that has not been removed by the cleaning processes. Ratios of forbs to grasses will vary in commercial seed mixes. Typical mixes include ratios of 50/50 or 60/40 and 66/33 forb/grass seed. For purchased seed, it is preferable to buy a grass mix and a forb mix separately and create a mix to ensure that the most desired species are acquired. If legumes are used in the forb mix, make certain that the appropriate inoculant is included with the seed.

Seed harvested from native stands may vary considerably from one season to the next in quantity, quality, and species diversity. To increase diversity in the planting, it is recommended that the manager use seed that is harvested in two different years (Kurtz 2001). Once gathered, the seed needs to be dried, threshed, separated from the heads, and properly cleaned and stored. Seed should be dried shortly after harvesting to prevent loss during storage. Properly dried seeds have $5-14 \%$ moisture content during storage (Harrington 1972). When seeds are dried out below 5\%, their cell walls break down and enzymes become inactive, and seeds with moisture content from $14-30 \%$ are often lost to microorganisms and fungi. Moisture levels above $30 \%$ will induce germination (Apfelbaum et al. 1997). Seeds often need treatments replicating natural processes to germinate well. Interseeding an area already planted or partially established during the following year will increase the diversity of the planting, because some species do not grow well in an open seedbed. Seeding rates are variable and depend on the species composition of the mix. If the seed is purchased, recommendations are generally provided for the mix. For hand-collected seed, a general seeding rate guideline is 10 pounds of clean, pure seed per acre and may be as high as 30 pounds per acre for rough, clean, hand-collected seed, however, the rate will vary depending on the species chosen.

Interseeding. Interseeding refers to the process of planting seed directly into existing vegetation without plowing or herbiciding. This method is preferred where there are many conservation species in an area to be preserved and can serve to increase diversity in the planting. Compared to plowing, plant establishment by overseeding takes considerably longer because of competition from existing plants. A seed mix will develop slowly over four to five years when a site is interseeded.

Mosaic seeding. This technique involves various seeding rates and species mixes for different sites within the restoration area. It allows for adjusting the planting to correspond to topography and the species continuum found along moisture and slope gradients. Additionally, mosaic seeding can be used to increase botanical diversity. For example, planting more forbs in an area may allow species to survive that will not compete well with grasses. Planting in this manner allows for unevenness or patches to develop, which mimics a natural area. These patches create different types of habitat and result in greater faunal diversity.

Planting. A no-till drill specifically designed for seeding the fluffy seeds characteristic of native grasses is recommended for restoration plantings. Native grass drills have double disk openers with depth bands and large-diameter drop tubes that don't allow seed to hang up in the tubes (NRCS 
2006). Placing the seed at the proper depth is critical to planting success. Proper seeding depth is $1 / 4$ in. to $1 / 2$ in. maximum (NRCS 2006), though it is preferable to seed on the surface of the ground than for the seed to be buried too deep. Conventional drills do not have depth bands or feed mechanisms that can handle fluffy seed. Cultipacker type seeders will not meter the fluffy seeds and are not as effective in proper seed placement (NRCS 2006). Some soil and water conservation districts rent these drills. A three-point broadcast seeder or a fertilizer spreader can be used and will cover a six foot-wide strip. Care should be taken to ensure that the seed is spread uniformly. Once the seed is broadcast or drilled, the site should be harrowed lightly and rolled until the soil is firm, this will prevent the soil from washing away prior to vegetation establishment.

Hydroseeding. Utilizing hydroseeding (and artificial mulching methods) may be the best way to plant on steep slopes. In this case, only grasses and certain shrub and tree seed that is light can be used. Seed may then be planted up to 200 feet from the hydro seeding source.

Cuttings. Roots of plants that naturally spread by root suckers can be cut into three-inch pieces and used for plantings. Cuttings can also be made from branches of soft-wooded tress such as Salix (Willows) and Populus (poplars) that root adventitiously, and therefore are adapted for use in biotechnical treatments (as further described below).

Sprigging. Underground rhizomes, tubers, and pieces of plants that can easily root may be hand broadcast, plugged or mechanically planted. Many grasses and some herbaceous plant species (lilium spp. for example) can be planted this way.

Containerized Plants. Containerized plants and live-root plants are available through the NRCS plant centers, or a local commercial nursery. Other sources of plants include harvesting plants on site which can be potted, bare-root, or incorporated into biotechnical treatments. Plant rescues offer another possible source (Bailey 2015; Bailey and Martin 2007a, 2007b).

Decision Matrix. The Decision Matrix integrates site conditions and planting methods. Not all of the parameters listed will apply to all sites, but this list represents some of the more important materials and energy environment considerations for successful projects (Table 1).

\section{Table 1. Decision Matrix for selecting planting methods based upon site conditions (adapted from Bailey et al. 2013).}

\begin{tabular}{|c|c|c|c|c|c|c|c|c|}
\hline \multirow[b]{2}{*}{$\begin{array}{l}\text { Factor or } \\
\text { Failure } \\
\text { Process }\end{array}$} & \multirow[b]{2}{*}{$\begin{array}{l}\text { Intensity } \\
\text { or Type of } \\
\text { Condition }\end{array}$} & \multicolumn{7}{|c|}{ Planting Techniques } \\
\hline & & \begin{tabular}{|c} 
Live \\
Staking \\
\end{tabular} & \begin{tabular}{|c} 
Live \\
Fascine \\
\end{tabular} & $\begin{array}{c}\text { Brush- } \\
\text { Layering }\end{array}$ & $\begin{array}{l}\text { Branch- } \\
\text { Packing } \\
\end{array}$ & $\begin{array}{l}\text { Live } \\
\text { Crib } \\
\text { Wall }\end{array}$ & $\begin{array}{c}\text { Live } \\
\text { Slope } \\
\text { Grating } \\
\end{array}$ & $\begin{array}{c}\text { Vegetated } \\
\text { Geogrid or } \\
\text { Geocell }\end{array}$ \\
\hline \multirow{3}{*}{$\begin{array}{l}\text { Slope } \\
\text { gradient }\end{array}$} & Steep & & $X$ & $x$ & $\mathrm{~N} / \mathrm{A}$ & $x$ & $x$ & $x$ \\
\hline & Moderate & & $X$ & $X$ & $N / A$ & $x$ & $x$ & $x$ \\
\hline & Gentle & $x$ & $X$ & & $\mathrm{~N} / \mathrm{A}$ & $x$ & & \\
\hline \multirow{2}{*}{ Slope height } & High & $x$ & $x$ & $x$ & $\mathrm{~N} / \mathrm{A}$ & & $X$ & $x$ \\
\hline & Low & $x$ & $x$ & $x$ & $\mathrm{~N} / \mathrm{A}$ & $X$ & $x$ & $X$ \\
\hline \multirow{2}{*}{ Soil depth } & Deep & $X$ & $X$ & $X$ & $X$ & N/A & $\mathrm{N} / \mathrm{A}$ & $x$ \\
\hline & Shallow & $X$ & $X$ & & & N/A & $\mathrm{N} / \mathrm{A}$ & \\
\hline
\end{tabular}




\begin{tabular}{|c|c|c|c|c|c|c|c|c|}
\hline \multirow{3}{*}{$\begin{array}{l}\text { Soil } \\
\text { erodibility }\end{array}$} & High & & $X$ & & & $\mathrm{~N} / \mathrm{A}$ & $x$ & $x$ \\
\hline & Moderate & & $x$ & $x$ & & N/A & $x$ & $x$ \\
\hline & Low & & $x$ & $x$ & $x$ & N/A & $x$ & $x$ \\
\hline \multirow{2}{*}{ Soil strength } & Moderate & $x$ & $x$ & $x$ & $\mathrm{~N} / \mathrm{A}$ & N/A & $\mathrm{N} / \mathrm{A}$ & N/A \\
\hline & Low & $\mathrm{N} / \mathrm{A}$ & $x$ & $x$ & $\mathrm{~N} / \mathrm{A}$ & N/A & $\mathrm{N} / \mathrm{A}$ & N/A \\
\hline \multirow{2}{*}{ Slope type } & Cut & $x$ & $x$ & $x$ & $x$ & & $x$ & \\
\hline & Fill & $x$ & $x$ & $x$ & $x$ & $x$ & & $x$ \\
\hline $\begin{array}{l}\text { Superficial } \\
\text { erosion }\end{array}$ & & $X$ & $\mathrm{X}$ & & $X$ & & $X$ & \\
\hline \multirow{2}{*}{$\begin{array}{l}\text { Mass } \\
\text { Movement }\end{array}$} & Shallow & $x$ & $x$ & $x$ & $x$ & $x$ & & \\
\hline & Moderate & & & $x$ & & & & $x$ \\
\hline
\end{tabular}

N/A = Not applicable

In naturally variable tidal and estuarine environments, even vegetation that can hold shorelines in place when mature may be vulnerable during the establishment phase and may take several growing seasons to establish. In all but the lowest energy environments, a bioengineered or combination of vegetation with structural or selected hard armor materials will be the best solution for both short and longer-term situations. In some cases, retrofitting a marginal structural solution with vegetation may give the project the added stability required while conferring the other benefits of native vegetation described above. Even an existing riprap or gabion wall can be interseeded or interplanted with vegetation to confer some habitat or water quality benefit. A number of specific site and design considerations for selecting setting- appropriate techniques could be incorporated per living shoreline guidance design (Moon 2007). References such as Gray and Sotir (1996) and Lieser and Gray (1982) describing treatment options which can be used to address shoreline conditions.

\section{ADDITIONAL CONSIDERATIONS}

Salinity. The following table lists native plants that have tolerance to salt spray or saline soils. These lists are important for successful planting in coastal areas where there are tidal influences causing saline soils and exposure to salt spray on plantings. Table 2 lists grasses, Table 3 lists native shrubs, and Table 4 lists native trees that are known to tolerate various levels of salt exposure.

Hydrologic Regime. The extent of saturation or inundation is a determining factor for the success of wetland plant communities when establishing native plants in placement areas. Hydrophytes are plants that are adapted to life in water or in saturated conditions. Careful evaluation of daily tidal fluctuations, non-tidal inundation, and water budget allocations resulting in ponding, flooding, soil surface inundation, or soil saturation are important considerations when selecting plants for propagation in placement areas. 
Table 2. Grasses tolerant to salt spray or saline soils.

\begin{tabular}{|l|l|l|l|}
\hline Common Name & Latin Name & G & Tolerance \\
\hline \hline Seashore Paspalum & Paspalum viganatum & G & Very high \\
Saltmeadow Cordgrass & Spartina patens & G & Very high \\
Smooth Cordgrass & Spartina alternifolia & G & Highest \\
Sea oats & Uniola paniculata & G & Very high \\
Creeping Bent grass & Agrostis palustris & G & High \\
\hline
\end{tabular}

*G=Graminoid

Table 3. Shrubs with tolerance to salt spray or saline soils (Virginia Cooperative Extension 2010).

\begin{tabular}{|c|c|c|c|}
\hline Common Name & Latin Name & D or $E$ & Zones \\
\hline Saltbush & Baccharis halmifolia & D & $3-7 / 7-1$ \\
\hline Beautyberry & Callicarpa americana & $\mathrm{D}$ & $5-10 / 12-3$ \\
\hline Red osier dogwood & Cornus sericea & $\mathrm{D}$ & $5-8 / 8-3$ \\
\hline Inkberry & Ilex glabra & E & 5-9/9-5 \\
\hline Common juniper & Juniperus communis & E & | 3-9/9-1 \\
\hline Shore juniper & Juniperus conferta & |E & $5-9 / 9-3$ \\
\hline Wax myrtle & Myrica cerifera & $E$ & |6-9/9-6 \\
\hline Bayberry & Myrica pennsylvanica & $D$ & 3-6/6-1 \\
\hline Purple-leaf sand cherry & Prunus $x$ cistena & D & $4-8 / 8-1$ \\
\hline Beach plum & Prunus maritime & $D$ & $3-6 / 6-1$ \\
\hline Staghorn sumac & Rhus typhina & $\mathrm{D}$ & 3-8/8-1 \\
\hline Elderberry & Sambucus canadensis & D & 4-9/9-1 \\
\hline Highbush blueberry & Vaccinum corymbosum & $D$ & 5-9/9-2 \\
\hline Arrowwood & Viburnum dentatum & D & 3-8/8-1 \\
\hline $\begin{array}{l}\text { European cranberry- } \\
\text { bush viburnum }\end{array}$ & Viburnum opulus & D & 4-8/8-1 \\
\hline
\end{tabular}

*D=Deciduous; $E=$ Evergreen 
Table 4. Trees with tolerance to salt spray or saline soils (adapted from Virginia Cooperative Extension 2010).

\begin{tabular}{|l|l|l|l|l|}
\hline Common Name & Latin Name & D or E* & Tolerance & Zones \\
\hline \hline Gray birch & Betula populifolia & D & Salt spray & $3-7 / 7-2$ \\
Catalpa & Catalpa speciosa & D & Salt spray & $4-8 / 8-1$ \\
Hackberry & Celtis laevigata & D & Salt spray & $5-9 / 9-3$ \\
Common persimmon & Diospyros virginiana & D & Saline soils, salt spray & $7-9 / 9-7$ \\
White ash & Fraxinus americana & D & Saline soils, salt spray & $6-9 / 9-3$ \\
Green ash & Fraxinus pennsylvanica & D & Salt spray & $4-9 / 9-1$ \\
Honeylocust & Gleditsia triacanthos & D & Saline soils, salt spray & $3-7 / 7-1$ \\
American holly & Ilex opaca & E & Salt spray & $5-9 / 9-5$ \\
Black walnut & Juglans nigra & D & Saline soils, salt spray & $5-9 / 9-5$ \\
Eastern red cedar & Juniperus virginiana & E & Saline soils, salt spray & $3-9 / 9-1$ \\
Sweetgum & Liquidambar styraciflua & D & Salt spray & $\mid 6-9 / 9-1$ \\
Black gum & Nyssa sylvatica & D & Salt spray & $5-9 / 9-5$ \\
Longleaf pine1 & Pinus palustris & E & Salt spray & 7-9/9-3 \\
Black locust & Robinia pseudoacacia & D & Saline soils, salt spray & $4-9 / 9-4$ \\
Weeping willow & Salix alba & Dalt spray & $6-9 / 9-5$ \\
\hline
\end{tabular}

${ }^{*} \mathrm{D}=$ Deciduous; $\mathrm{E}=$ Evergreen

Maintenance. Establishing a native plant community may require ongoing surveillance and control of the invasive species. The ability to respond quickly, so that annual weeds are eradicated before they go to seed, can make a significant contribution to invasive plant control. During the first year of establishment, plants primarily develop roots and aboveground growth is short. By contrast, weeds grow fast and tall aboveground in the first year, thus, mowing during this period will help the native plants compete for light. However, it is important to set the mower height above the top of the native seedlings.

Careful attention to local weather conditions is necessary to ensure proper watering for all plantings, if applicable. This will be critical in the first year of establishment, and may be required for two and three years after planting in arid and semi-arid regions. However, one exception may be watering drought tolerant plant species.

Herbicide Application. Systemic herbicide treatments applied directly to unwanted invasive herbaceous plant leaves or cut stems of brush and invading trees can help in keeping the native plantings free of competition. Most common agricultural weeds that occur in a new planting will become reduced as the grasses and forbs develop. It is important to avoid management practices such as plowing or disking, which expose the soil, thin the stand, and invite annual weedy species. 
Resources. Many technical articles and books, websites, and other information on biotechnical planting and plantings for various purposes. For example the Virginia Coastal Zone Management Program (http://www.deq.virginia.gov/expor t/sites/default/coastal/ livingshore.html) offers detailed guidance documents describing selected methods for stabilizing beaches, shorelines, dunes and bluffs, and for breaking wave energy using living shoreline techniques (Moon 2007). It must be noted that scarce funding is a constraint for planting such placement areas. Collaborations with stakeholders and partners are essential to obtaining funding for planting and monitoring to ensure success. Plant community species are listed in the website excel table linked to the EWN page at www. Engineering WithNature.org.

SUMMARY: Establishing native vegetation at CDFs and DMPAs has the potential to provide a number of ecological and engineering benefits such as erosion control and de-watering effects. The current report describes recommendations/tools to support selection of vegetation species and planting techniques. Additional considerations related to salinity and maintenance of plant communities are also discussed.

ADDITIONAL INFORMATION: This EWN TN was prepared by Pamela Bailey, Research Botanist and Landscape Architect, Sarah Miller, Research Ecologist, Timothy Cary, Research Agronomist, Scott Bourne, Research Physical Scientist, and Tosin Sekoni, Research Ecologist, U.S. Army Engineer Research and Development Center. The study was conducted as an activity of the EWN Initiative. For more information please consult www. Engineering WithNature.org or contact the Program Managers, Dr. Todd Bridges and Dr. Jeff K. King, at Todd.S.Bridges@usace.army.mil and Jeffrey.K.King@usace.army.mil. This TN should be cited as follows:

Bailey, P., S. Miller, T. Cary, S. Bourne and T. Sekoni. 2019. "Plant community approach to establishing vegetation on DMPAs and CDFs." EWN Technical Notes Collection, EWN/TN EWN-19-2. Vicksburg, MS: U.S. Army Engineer Research and Development Center.

ACKNOWLEDGEMENTS: The authors would like to thank Dr. David Price, Research Plant Ecologist, and Dr. Jacob Berkowitz, Research Soil Scientist, for their comments on this TN. Special acknowledgement also go to Dr. Bruce Pruitt and Dr. Burton Suedel for their formal peer review.

\section{REFERENCES}

Apfelbaum, S. I., B. J. Bader, F. Faessler, and D. Mahler. 1997. Obtaining and processing seeds. In The Tallgrass Restoration Handbook for Prairies, Savannas, and Woodlands. Washington DC: Island Press 99-126.

Asano, T. 2006. Wave attenuation and sediment deposition due to coastal vegetation. Journal of Global Environment Engineering 11:29-44.

Bailey, P. J. Seiter, J. Kelly, B. Lafferty, S. Bourne, and M. Chappell. 2015. Pre and Post Mining and Reclamation Monitoring at East Lynn, Dewey, and Fishtrap Lakes. Final Report for Huntington Corps of Engineers District. Vicksburg, MS: U.S. Army Engineer and Research and Development Center.

Bailey, P. 2014. A Sustainable Design Manual: Engineering With Nature using Native Plant Communities. ERDC/TN EWN-17-2. U.S. Army Corps of Engineers EWN Program. Vicksburg, MS: Engineer Research and Development Center. 
Bailey, P., S. Miller, S. Bourne, and T .Cary. 2013. Indigenous Plantings to Prevent Erosion on Army Lands Within the Chesapeake Bay. U.S. Army Corps of Engineers for OASCIM. ERDC-LR-13-2. Vicksburg, MS: Engineer Research and Development Center.

Bailey, P. and C. O. Martin. 2007a. Overview of Prairie Planting Techniques and Maintenance Requirements. ERDC TN-EMRRP-ER-05. Vicksburg, MS: U.S. Army Engineer and Research and Development Center.

Bailey, P., and C. O. Martin. 2007b. Regional Availability of Plants for Prairie Restoration. EMRRP Technical Notes Collection. ERDC TN-EMRRP-SI-31. Vicksburg, MS: U.S. Army Engineer Research and Development Center.

Berkowitz, J. F, S. Kim, N. R. Beane, D. E. Evans, E. Summers, B. Suedel, M. Flanagin, and J. Corbino. 2017. A Multi-Factor Ecosystem Assessment of Wetlands Created Using a Novel Dredged Material Placement Technique in the Atchafalaya River, Louisiana. ERDC/EL TR-17-5. Vicksburg, MS: U.S. Army Engineer Research and Development Center.

Brenzy, O., I. Metha, and R. K. Sharma. 1973. Studies on evapotranspiration of some aquatic weeds. Weed Science 21(3):197-204. https://doi.org/10.1017/S0043174500032112.

Bridges, T. S., P. W. Wagner, K. A. Burks-Copes, M. E. Bates, Z. A. Collier, C. J. Fischenich, J. Z. Gailani, L. D. Leuck, C. D. Piercy, J. D. Rosati, E. J. Russo, D. J. Shafer, B. Suedel, E. A. Vuxton, and T. V. Wamsley. 2015. Use of Natural and Nature-Based Features (NNBF) for Coastal Resilience. ERDC SR-15-1. Vicksburg, MS: US Army Corps of Engineers: Engineer Research and Development Center.

Broome, S. W., E. D. Seneca, and W. W. Woodhouse. 1988. Tidal salt marsh restoration. Aquatic Botany 32(1-2):122.

Comoss, E. J., D. A. Kelly, and H. J. Leslie. 2002. Innovative erosion control involving the beneficial use of dredge material, indigenous vegetation and landscaping along the Lake Erie shoreline. Ecological Engineering 19(3):203-210.

Danielsen, F., M. K. Sørensen, M. F. Olwig, V. Selvam, F. Parish, N. D. Burgess, T. Hiraishi, V. M. Karunagaran, M. S. Rasmussen, L. B. Hansen, and A. Quarto. 2005. The Asian tsunami: A protective role for coastal vegetation. Science 310(5748):643. DOI: 10.1126/science.1118387.

Gómez-Aparicio, L., R. Zamora, J. M. Gómez, J. A. Hódar, J. Castro, and E. Baraza. 2004. Applying plant facilitation to forest restoration: a meta-analysis of the use of shrubs as nurse plants. Ecological Applications 14(4):11281138. https://doi.org/10.1890/03-5084.

Gray, D. H., and R. B. Sotir. 1996. Biotechnical and Soil Bioengineering Slope Stabilization. A Practical Guide for Erosion Control. New York, NY: John Wiley and Sons, Inc. 10158-001.

Gray, D. H., and A. T. Leiser. 1982. Biotechnical Slope Protection and Erosion Control. Department of Civil Engineering the University of Michigan. Malabar, FL: Department of Krieger Publishing Company.

Grossman, D. H., D. Faber-Langendoen, A. S. Weakly, M. Anderson, P. Bourgeron, R. Crawford, K. Goodin, S. Landaal, K. Metzler, K. Patterson, M. Pyne, M. Reid, and L. Sneddon. 1998. International Classification of Ecological Communities: Terrestrial Vegetation of the United States. Volume I. The National Vegetation Classification System: Development, Status, and Applications. Arlington, VA: The Nature Conservancy.

Harrington, J. F. 1972. Seed storage and longevity. In Seed Biology, Vol.3. New York Academic Press.

Jones, K., and E. Hanna. 2004. Design and implementation of an ecological engineering approach to coastal restoration at Loyola Beach, Kleberg County, Texas. Ecological Engineering 22(4):249-261.

Kramer, P. J., and J. S. Boyer. 1983. Water relations of plants and soils. New York, New York: Academic Press.

Kurtz, C. 2001. A Practical Guide to Prairie Reconstruction. Ames, Iowa: University of Iowa Press.

Moon, S. 2007. Living Shorelines Web Page. Virginia Department of Environmental Quality Coastal Zone Management. Accessed 18 May 2018. (http://www.deq.state.va.us/export/sites/default/coastal/livingshore.html Accessed 5/24/2018.

Nature serve explorer. nd. Accessed 18 May 2018. www.natureserve.org.

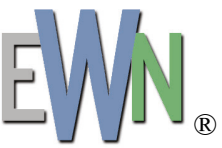


February 2019

Natural Resources Conservation Service (NRCS). 2006. Native Grass Seed Availability Purchasing Strategies and Handling Guidelines. Plant Materials Technical Note, Northeast, Mid-Atlantic and Great Lakes Plant Material Program, U.S. Department of Agriculture. https://www.scribd.com/document/110012742/Native-Grass-SeedAvailability-Purchasing-Strategies-and-Handling-Guidelines.

Pisek, A., and E. Berger. 1938. KutikulSre transpiration and trockenrensistenzisolierter blatter und sprosse. Planta 28 : $124-155$.

Shearman, D. C. 1989. Perennial ryegrass cultivar evapotranspiration rates. HortScience 24(5): 767-769.

Smith, K. E., M. K. Banks, A. P. Schwab. 2009. Dewatering of contaminated sediments: Greenhouse and field studies. Ecological Engineering. 35:1523-1528.

Smith, P. L., B. Wilson, C. Nadolny, and D. Lang. 2000. The ecological role of the native vegetation of New South Wales.

U.S. Army Corps of Engineers (USACE). 1980. Landscape Development of Confined Dredged Material Disposal Sites. Engineer Manual \#1110-2-5024.

Virginia Cooperative Extension. 2010. Trees and Shrubs that Tolerate Saline Soils and Salt Spray Drift. Http://pubs.ext.vt.edu.

Walker, R., B. Bendell, and L. Wallendorf. 2011. Defining engineering guidance for living shoreline projects. In Coastal Engineering Practice 1064-1077. 